\title{
HUBUNGAN ANTARA KELEKATAN DENGAN ORANGTUA DAN KEINTIMAN DALAM BERPACARAN PADA DEWASA AWAL
}

\author{
Cahyaning Utami \\ Heru Astikasari Setya Murti \\ Fakultas Psikologi Universitas Kristen Satya Wacana \\ uutcahya@gmail.com \\ Email: heru.astika@gmail.com
}

\begin{abstract}
Attachment is a lasting effective bond characterized by a tendency to seek and maintain the closeness of one individual to another, which can provide a sense of security, depending on the quality of the relationship. Based on the quality of the relationship, indivisuals will develop an internal working model that can lasts throughout a lifetime and will likely to affect the intimate relationships during adulthood. The aim of this research was to investigate the relationship between attachment and intimacy in young adults. One hundred and four subjects participated in this research, consisted in early adulthood between the age of 20 to 30 years old, who were in a relationship dating. The instruments of this research is Inventory of Parent and Peer Attachment (IPPA) scale and Personal Assessment of Intimacy in Relationship (PAIR) scale. The research shows a corelation beetwen parent attachment (mother) and intimacy $r=0,320 p=0,001(p<0,05)$ and corelation of parent attachment (father) with intimacy $r=0,256 p=0,009(p<0,05)$. The result shows a significant positive relationship between parent attachment and intimacy it means the higher of the attachment then will also higher of intimacy in relatioonship.
\end{abstract}

Keywords: attachment, intimacy, young adulthood

\section{INTISARI}

Kelekatan adalah ikatan efektif abadi yang dikarakteristikkan dengan kecenderungan untuk mencari dan mempertahankan kedekatan antara satu individu dengan yang lain, yang dapat memberikan rasa aman, tergantung dari kualitas hubungan tersebut. Berdasarkan kualitas hubungan tersebut, terbentuk internal working model yang bertahan sepanjang waktu dan dapat memengaruhi hubungan dengan pasangan romantis individu tersebut, di masa dewasa yang berkaitan dengan intimacy. Penelitian ini bertujuan untuk mengetahui hubungan antara kelekatan dengan intimacy pada masa dewasa awal. Metode penelitian yang digunakan adalah penelitian kuantitatif. Subjek dalam penelitian ini adalah individu pada masa dewasa awal yang berusia sekitar 20 sampai dengan 30 tahun dan sedang menjalin hubungan berpacaran. Subjek berjumlah 104 orang. Alat ukur yang digunakan adalah skala Inventory of Parent and Peer Attachment (IPPA) dan skala Personal Assessment of Intimacy in Relationship (PAIR). Hasil penelitian menunjukkan korelasi parent attachment (mother) dengan intimacy adalah $r=0,320$ $\mathrm{p}=0,001(\mathrm{p}<0,05)$ dan parent attachment (father) dengan intimacy adalah $\mathrm{r}=0,256 \mathrm{p}=0,009$ $(\mathrm{p}<0,05)$. Ini menunjukkan adanya hubungan positif yang signifikan antara parent attachment dengan intimacy, yang berarti jika semakin tinggi attachment yang dimiliki individu semakin tinggi juga intimacy dalam berpacaran begitu juga sebaliknya.

Kata Kunci : dewasa awal, keintiman, kelekatan orangtua 
$\mathrm{S}$

etiap manusia dalam masa kehidupannya pasti akan mengalami tahapan perkembangan dan harus menjalani tugas-tugas perkembangan. Menurut teori Erikson (dalam Santrock, 2007) kemajuan manusia dicapai melalui delapan tahap perkembangan yang berlangsung seumur hidup. Di dalam tiap tahapan tersebut, individu dihadapkan pada sebuah krisis yang merupakan suatu tugas perkembangan unik yang harus diselesaikan. Krisis ini bukanlah sebuah bencana, namun merupakan sebuah titik balik yang ditandai oleh meningkatnya kerentanan dan potensi seseorang. semakin individu berhasil menyelesaikan krisis yang dihadapinya, semakin sehat perkembangan individu tersebut (Hopkins dalam Santrock, 2007).

Pada masa dewasa awal yaitu pada usia 20-30an individu mengalami krisis keintiman versus isolasi yang menurut Erikson (dalam Santrock, 2007) merupakan tahap keenam dari perkembangan, yang dialami individu selama masa dewasa awal. Di masa ini, individu menghadapi tugas perkembangan yang berkaitan dengan pembentukan relasi intim dengan orang lain. Erikson mendeskripsikan keintiman sebagai menemukan diri sendiri di satu sisi, namun kehilangan diri sendiri di sisi lain. Jika seorang dewasa muda membentuk persahabatan yang sehat dan sebuah relasi yang intim dengan orang lain, keintiman akan dicapai; jika tidak, ia akan merasa terkucil. Keintiman merupakan salah satu tugas perkembangan yang sangat penting bagi dewasa dini (Erikson dalam Papalia, 2004). Keintiman ini diwujudkan dengan menjalin hubungan dengan orang lain, saling percaya dan membentuk suatu komitmen dalam berpacaran.

Menurut Guerney dan Arthur (dalam Dacey \& Kenny, 1997) berpacaran adalah aktivitas sosial yang membolehkan dua orang yang berbeda jenis kelaminnya untuk terikat dalam interaksi sosial dengan pasangannya yang tidak ada hubungan keluarga. Menurut Erikson (dalam Santrock, 2003) pengalaman romantis pada masa remaja dipercaya memainkan peran yang penting dalam perkembangan identitas dan keakraban. Pacaran pada masa remaja membantu individu dalam bentuk hubungan romantis selanjutnya dan bahkan pernikahan pada masa dewasa.

Dalam suatu hubungan berpacaran, diperlukan rasa saling percaya, terbuka dan saling berbagi, dimana hal-hal tersebut adalah gambaran perasaan yang menunjukkan adanya suatu keintiman dalam berpacaran. Keintiman secara umum ditandai oleh perasaan penerimaan, kedekatan, komitmen, dan kepercayaan antara kedua belah pihak. Menurut Erikson (dalam Marcia, \& James, 1993) individu yang memiliki kemampuan keintiman akan mampu berkomitmen pada pilihan yang telah diambilnya walaupun untuk mempertahankannya membutuhkan pengorbanan dan banyak perundingan. 
Olson (1981) mengacu pada aspekaspek proses keintiman dengan membedakan antara pengalaman intim dan hubungan intim. Pengalaman intim adalah kedekatan perasaan atau berbagi dengan yang lain dalam satu, lebih dari tujuh area. Hubungan intim pada umumnya adalah seorang individu yang berbagi pengalaman intim di beberapa area, dan ada harapan bahwa pengalaman dan hubungan akan bertahan dari waktu ke waktu. Keintiman adalah kedekatan dan perasaan hangat yang dimiliki oleh orang-orang tertentu (Olson \& Defrain, 2006). Selain itu, keintiman menunjukkan bukti bahwa individu terhubung dan dekat dengan orang yang dicintainya. Keintiman juga merupakan emosi yang membuat individu merasa lebih dekat satu sama lain, emosi-emosi tersebut seperti menghargai, afeksi dan saling memberikan dukungan, serta merasakan keintiman dalam konteks dua orang individu berbagi banyak informasi personal (Lefrancois, 1993). Dengan demikian, dapat disimpulkan bahwa keintiman merupakan kondisi interpersonal dan emosional yang dialami oleh dua orang individu dalam konteks hubungan romantis.

Menurut Linder (2007), keintiman dalam hubungan berpacaran dibangun dengan kepercayaan, pengertian, penerimaan, dan menghargai pasangan. Kurangnya rasa percaya terhadap pasangan dapat menimbulkan kecemburuan. Hal ini didukung oleh penelitian yang dilakukan oleh Yeniza (2007), yang menunjukkan hasil bahwa ada hubungan berarah negatif yang sangat signifikan antara keintiman dengan kecemburuan pada remaja yang berpacaran. Kurangnya keintiman dalam sebuah hubungan berpacaran dipengaruhi oleh beberapa faktor menurut Cox (1978), yakni pengalaman masa lalu, kecemasan akan identitas diri, ketakutan akan terungkapnya kelemahan, membawa kekesalan atau dendam masa lalu ke masa kini, konflik masa kecil yang tidak terselesaikan, ketakutan akan mengungkapkan perasaan yang tidak nyaman bagi dirinya.

Salah satu pengalaman masa lalu yang dapat mempengaruhi dan menentukan kemampuan individu dalam menjalin keintiman adalah kualitas kelekatan yang terbentuk pada masa kecil (Agusdwitanti, Tambunan \& Retnaningsih 2015). Berdasarkan kualitas hubungan anak dengan orangtua pada masa kecil, maka anak akan mengembangkan konstruksi mental mengenai diri sendiri dan orang lain yang akan menjadi mekanisme penilaian terhadap penilaian lingkungan (Bowlby dalam Pramana, 1996). Anak yang merasa yakin terhadap penerimaan lingkungan akan mengembangkan kelekatan yang aman dengan figur lekatnya dan mengembangkan rasa percaya tidak saja pada orangtuanya namun juga pada lingkungan (Ervika, 2005). 
Orangtua merupakan tempat belajar anak untuk yang pertama kali. Segala perilaku orangtua terhadap anak akan terinternalisasi hingga remaja bahkan usia lanjut. Macam-macam sikap orangtua adalah mengasuh anak, dilihat dari cara orangtua merespon dan memenuhi kebutuhan anak, akan membentuk suatu ikatan emosional antara anak dengan orangtua sebagai figur pengasuh. Ikatan emosi yang terbentuk antara anak dan orangtua sebagai figur pengasuh oleh Bowlby disebut sebagai kelekatan atau attachment (Yessy, 2003). Bowlby dan Ainsworth menjelaskan kelekatan dalam buku Colin (1996) sebagai ikatan afektif abadi yang dikarakteristikkan dengan kecenderungan untuk mencari dan mempertahankan kedekatan dengan figur tertentu. Ringkasnya, kelekatan ialah suatu ikatan emosional yang kuat antara bayi dengan pengasuhnya (Santrock, 2002) Attachment merupakan suatu hubungan yang didukung oleh perilaku lekat yang dirancang untuk memelihara hubungan tersebut (Durkin dalam Eliasa, 2000)

Menurut Bowlby dan Ainsworth (dalam Cassidy, 1999) perilaku lekat merupakan suatu tingkah laku yang ditunjukkan oleh bayi kepada orang tuanya. Perilaku lekat ini adalah perilaku anak yang menangis, mendekati, mencari kontak dan berusaha untuk mempertahankan kontak pada orangtuanya ketika anak sedang mencari kenyamanan atau ketenteraman. Aspek kelekatan menurut Greenberg dan
Armsden (1987) adalah (1) Kepercayaan: Menunjukkan bahwa remaja percaya bahwa orang tua dan teman sebaya mengerti dan memahami kebutuhan dan keinginan mereka, (2) Komunikasi: Menunjukkan persepsi remaja mengenai orang tua dan teman sebaya yang peka dan mau mendengarkan bagian emosi mereka dan menilai tingkat serta kualitas keterlibatan dan komunikasi verbal dengannya, (3) Keterasingan: Menunjukkan perasaan remaja mengenai keterasingan, kemarahan, dan pengalaman pelepasan dari hubungan kelekatan dengan orang tua dan teman sebaya.

Penelitian sebelumnya yang dilakukan oleh Agusdwitanti, Tambunan, dan Retnaningsih (2015) menyimpulkan bahwa kelekatan diperlukan agar intimasi dapat terjalin lebih erat. Hal ini perlu ditekankan pada individu dalam menjalin relasi tanpa batasan waktu kebersamaan sejak awal bertemu. Artinya, dengan kelekatan yang erat individu dapat memiliki intimasi di awal hubungan dan bahkan saat hubungan sudah lama terjalin. Namun, penelitian yang telah dilakukan oleh Sidjabat, (2015) menemukan hasil bahwa tidak terdapat hubungan yang signifikan antara pola kelekatan ayah-anak perempuan dengan kapasitas kelekatan wanita terhadap lawan jenis pada masa dewasa awal.

Penelitian ini bertujuan untuk meneliti mengenai hubungan antara kelekatan dengan orangtua dan keintiman 
dalam berpacaran pada dewasa awal. Hipotesis yang diajukan adalah terdapat hubungan positif signifikan antara kelekatan orangtua dan keintiman dalam berpacaran pada dewasa awal.

\section{METODE PENELITIAN}

\section{Subjek penelitian}

Subjek dalam penelitian ini adalah individu dengan rentang usia 20-30 tahun berjumlah 104 orang dengan kriteria sedang menjalin hubungan berpacaran. Teknik pengambilan sampel yang digunakan dalam penelitian ini adalah teknik purposive sampling, yaitu teknik penentuan sampel dengan pertimbangan tertentu (Sugiyono, 2011)

\section{Alat Pengumpulan Data}

Skala yang digunakan untuk mengukur kelekatan dengan orangtua adalah skala kelekatan ayah dan ibu yang ada dalam Inventory of Parent and Peer Attachment yang terdiri dari 50 item dan dibagi menjadi 2 bagian (masing-masing 25 aitem) yang disusun berdasarkan 3 aspek yaitu Kepercayaan (10 aitem), Komunikasi (9 aitem), dan Keterasingan (6 aitem). Setelah diujicoba didapati bahwa ada 9 aitem yang gugur untuk skala kelekatan dengan ibu. Dari 9 item yang gugur terdapat 7 aitem bertahan untuk aspek kepercayaan, 7 aitem bertahan untuk aspek komunikasi, dan 2 aitem bertahan untuk keterasingan. Kemudian, untuk skala kelekatan dengan ayah terdapat 8a item yang gugur. Dari 8 aitem yang gugur terdapat 8 aitem bertahan untuk aspek kepercayaan, 7 aitem bertahan untuk aspek komunikasi, dan 2 aitem bertahan untuk aspek keterasingan. Reliabilitas untuk skala kelekatan ibu adalah 0.885 dan untuk skala kelekatan ayah adalah 0.943 .

Skala yang digunakan untuk mengukur keintiman adalah skala PAIR (Personal Assessment of Intimacy in Relationship) terdiri dari 36 pernyataan yang terbagi dalam 7 komponen. Terdapat 8 pernyataan untuk komponen keintiman emosional, 5 untuk komponen keintiman sosial, 4 pernyataan untuk komponen keintiman seksual, 5 pernyataan untuk komponen keintiman intelektual, 4 pernyataan untuk keintiman rekreasional, 9 pernyataan untuk komponen skala konvensional. Setelah diujikan, ada 7 aitem yang gugur. Dari 7 aitem yang gugur terdapat 7 aitem bertahan untuk komponen keintiman emosional, 3 aitem bertahan komponen keintiman sosial, 4 aitem bertahan pada komponen keintiman intelektual, 3 aitem bertahan untuk komponen keintiman rekreasional, 3 aitem bertahan pada komponen keintiman seksual, dan 8 aitem bertahan pada skala konvensional. Reliabilitas untuk keintiman adalah 0,926 , dan indeks daya beda aitem yang digunakan di kedua skala minimal 0,3. 


\section{Teknik analisis data}

Metode analisis data yang digunakan untuk menganalisa data adalah teknik korelasi product moment dari Karl Pearson.

\section{HASIL PENELITIAN}

\section{Uji Normalitas dan Linearitas}

Hasil perhitungan uji KolmogorovSmirnov Z pada kelekatan diperoleh nilai KS-Z sebesar $1,049(p=0.222 ; p>0,05)$, kelekatan pada ibu diperoleh nilai K-S-Z sebesar $0.762(p=0.608 ; p>0,05)$, dan kelekatan pada ayah diperoleh nilai K-S-Z sebesar $0,847(p=0,470 ; p>0,05)$, yang berarti bahwa data berdistribusi normal.

Hasil perhitungan linearitas menunjukkan bahwa hubungan kelekatan pada ibu dan keintiman linear $(F=1,125$; $\mathrm{p}=0.338 ; \mathrm{p}>0,05$ ) kemudian, kelekatan pada ayah dan keintiman juga linear $(F=$ 1,338; $p=0,127 ; p>0,05$ ).

\section{Analisis Deskriptif}

Tabel 1. Kriteria Skor Kelekatan pada Ibu

\begin{tabular}{|c|c|c|c|c|c|}
\hline No & Interval & Kategori & $\begin{array}{c}\text { Freku- } \\
\text { ensi }\end{array}$ & $\%$ & Mean \\
\hline 1. & $\begin{array}{c}48<\mathrm{x} \leq \\
64\end{array}$ & Tinggi & 77 & $74,03 \%$ & 50,73 \\
\hline 2. & $\begin{array}{c}32<\mathrm{x} \leq \\
48\end{array}$ & Sedang & 27 & $25,96 \%$ & \\
\hline 3. & $\begin{array}{c}16 \leq \mathrm{x} \leq \\
32\end{array}$ & Rendah & 0 & $0 \%$ & \\
\hline
\end{tabular}

Data di atas menunjukkan tingkat kelekatan pada ibu dari 104 subjek yang berbeda-beda, mulai dari tingkat sangat rendah hingga tinggi. Pada kategori rendah didapatkan skor 0\%, kategori sedang $25,96 \%$ kategori tinggi sebesar 74,03\%. Mean yang diperoleh adalah 50,73. Berdasarkan mean yang diperoleh, kelekatan pada ibu yang dimiliki oleh subjek berada pada kriteria yang tinggi.

Tabel 2. Kriteria Skor Kelekatan pada Ayah

\begin{tabular}{|c|c|c|c|c|c|}
\hline No & Interval & Kategori & $\begin{array}{c}\text { Freku- } \\
\text { ensi }\end{array}$ & $\%$ & Mean \\
\hline 1. & $\begin{array}{c}51<\mathrm{x} \leq \\
68\end{array}$ & Tinggi & 44 & $42,3 \%$ & \\
\hline 2. & $\begin{array}{c}34<\mathrm{x} \leq \\
51\end{array}$ & Sedang & 56 & $53,8 \%$ & 48,85 \\
\hline 3. & $\begin{array}{c}17 \leq \mathrm{x} \leq \\
34\end{array}$ & Rendah & 4 & $3,84 \%$ & \\
\hline
\end{tabular}

Data di atas menunjukkan tingkat kelekatan pada ayah dari 104 subjek yang berbeda-beda, mulai dari tingkat rendah hingga tinggi. Pada kategori rendah diperoleh presentase sebesar 3,84\%, kategori sedang sebesar 53,8\% dan kategori tinggi sebesar 42,3\%. Mean yang diperoleh adalah 48,85. Berdasarkan mean yang diperoleh, kelekatan pada ayah yang dimiliki oleh subjek dewasa awal berada pada kriteria yang sedang.

Tabel 3. Kriteria Skor Keintiman

\begin{tabular}{|c|c|c|c|c|c|}
\hline No & Interval & Kategori & $\begin{array}{c}\text { Freku- } \\
\text { ensi }\end{array}$ & $\%$ & Mean \\
\hline 1. & $\begin{array}{c}87<\mathrm{x} \leq \\
116\end{array}$ & Tinggi & 63 & $60,57 \%$ & 90,85 \\
\hline 2. & $\begin{array}{c}58<\mathrm{x} \leq \\
87\end{array}$ & Sedang & 38 & $36,5 \%$ & \\
\hline 3. & $\begin{array}{c}29 \leq \mathrm{x} \leq \\
58\end{array}$ & Rendah & 3 & $2,88 \%$ & \\
\hline
\end{tabular}

Data di atas menunjukkan tingkat keintiman dari 104 subjek yang berbedabeda, mulai dari tingkat rendah, sedang, 
hingga tinggi. Pada kategori rendah diperoleh presentase sebesar 2,88\%, kategori sedang sebesar 36,5\% dan kategori tinggi sebesar 60,57\%. Mean yang diperoleh adalah 90,85. Berdasarkan mean yang diperoleh, keintiman yang dimiliki oleh subjek dewasa awal berada pada kriteria yang tinggi.

\section{Analisis Hipotesis}

Dari hasil perhitungan uji korelasi product moment-Pearson untuk variabel kelekatan pada ibu dan keintiman didapatkan $r=0,320(p=0,001 ; p<0,05)$, yang berarti bahwa ada korelasi positif signifikan antara kelekatan pada ibu dengan keintiman, sementara berdasarkan hasil perhitungan uji korelasi product momentPearson untuk variabel kelekatan pada ayah dan keintiman didapatkan $r=0,256(p=$ 0,009; $\mathrm{p}<0,05)$, yang berarti bahwa ada korelasi positif signifikan antara variabel tersebut.

\section{PEMBAHASAN}

Berdasarkan penelitian yang telah dilakukan mengenai hubungan antara kelekatan dengan orangtua dan keintiman dalam berpacaran pada dewasa awal, diperoleh hasil yang menunjukkan adanya hubungan positif signifikan di setiap variabel, baik kelekatan pada ibu maupun ayah dan korelasinya dengan keintiman. Hasil penelitian ini menunjukkan bahwa ada keterkaitan antara pola kelekatan ibu dan ayah dengan keintiman di masa dewasa awal. Keduanya mendapatkan korelasi yang signifikan serta memiliki nilai $r$ yang tidak jauh berbeda.

Dari hasil penelitian juga dapat disimpulkan bahwa bahwa nilai $\mathrm{r}^{2}$ dari korelasi kelekatan pada ibu dan keintiman ini sebesar 0,1024. Hal ini berarti bahwa kelekatan pada ibu memiliki sumbangan efektif sebesar 10,24\% terhadap keintiman dalam berpacaran. Kemudian diketahui bahwa nilai $\mathrm{r}^{2}$ pada korelasi antara kelekatan ayah dan keintiman sebesar 0,0655 . Hal ini berarti kelekatan pada ayah memiliki sumbangan efektif sebesar 6,55\% terhadap keintiman dalam berpacaran sedangkan $83,21 \%$ sumbangan efektif lainnya berasal dari faktor lain.

Hasil penelitian ini sejalan dengan penelitian yang telah dilakukan oleh Agusdwitanti, Tambunan, dan Retnaningsih (2015) bahwa kelekatan dengan orangtua diperlukan agar keintiman dapat terjalin lebih erat. Dengan kelekatan yang aman, individu dapat mengembangkan keintiman di awal hubungan dan bahkan saat hubungan sudah lama terjalin. Hal ini didukung juga oleh penelitian yang telah dilakukan Vebrianingsih (2014) yang menyimpulkan bahwa gaya kelekatan aman mampu memprediksi tingkat keintiman dalam hubungan berpacaran pada individu di masa dewasa awal.

Seperti yang dijelaskan oleh Bowlby (1988) bahwa kecenderungan untuk membentuk ikatan emosional yang intim 
pada individu-individu tertentu, dianggap sebagai komponen dasar dari sifat manusia dan terus berlanjut sampai kehidupan dewasa bahkan sampai usia tua. Demikian pula sesuai dengan hasil penelitian Hazan dan Shaever (1987) yang menemukan bahwa kelekatan saat kecil berkaitan dengan hubungan romantis yang terjalin pada masa dewasa.

Berdasarkan hasil analisis deskriptif, menunjukkan subjek dalam penelitian ini memiliki kelekatan yang tergolong tinggi terutama kelekatan dengan ibu yaitu sebesar $74,03 \%$ sedangkan kelekatan dengan ayah tergolong kategori sedang dengan presentase sebesar 53,8\%. Tingginya kelekatan dengan ibu kemungkinan dapat dikarenakan individu memiliki ikatan emosional yang baik dengan ibu di masa kecil, ikatan emosional yang baik dapat terjadi karena adanya kepuasan individu terhadap ibu, misalnya setiap kali individu membutuhkan sesuatu maka ibunya mampu dan siap untuk memenuhinya (Baradja, 2005). Selain itu Bowlby (1998) juga mengatakan bahwa kelekatan merupakan suatu ikatan emosional yang dialami oleh anak yang terbentuk pada masa awal kehidupan dan diyakini memiliki dampak jangka panjang bagi individu yang bersangkutan dan ini akan terus berkembang sepanjang hidupnya, juga di usia dewasa awal. Hal ini serupa dengan yang diungkapkan oleh Erikson (dalam Lemme, 1995) yang mengatakan bahwa pengalaman kelekatan di masa kecil memberikan dampak jangka panjang pada hubungan interpersonal.

Kemudian individu dalam penelitian memiliki intimasi yang tergolong tinggi dengan presentase sebesar 60,57\%. Hal ini kemungkinan dikarenakan adanya perasaan terbuka dan saling percaya, saling berbagi dalam suatu hubungan dan adanya dukungan satu sama lain antar pasangan. adanya keterbukaan diri antar pasangan membuat individu merasa aman dan dekat satu sama lain sehingga dapat berbagi rasa mengenai masalah yang berkaitan dengan masalah intelektual, fisik atau seksual dan emosional (Biddle dalam Cox, 1978). Intimasi merupakan emosi yang membuat idividu merasa lebih dekat satu sama lain, emosi-emosi tersebut seperti menghargai, afeksi, dan saling memberikan dukungan (Shaver \& Clark 1994)

\section{KESIMPULAN}

Berdasarkan hasil penelitian dan pembahasan yang telah diuraikan maka hipotesis peneliti diterima dan didapatkan kesimpulan bahwa ada hubungan positif yang signifikan antara kelekatan dengan orangtua dalam berpacaran pada dewasa awal. Hal ini berarti semakin tinggi kelekatan dengan orangtua yang dimiliki oleh individu, maka akan semakin tinggi pula keintiman dalam berpacaran pada usia dewasa awal, begitu pula sebaliknya. Secara umum subjek memiliki tingkat kelekatan yang lebih tinggi dengan ibu dibandingkan 
dengan ayah, dan juga memiliki tingkat keintiman yang tinggi.

\section{SARAN}

1. Bagi individu yang menginjak usia dewasa awal, dari penelitian ini didapatkan hasil bahwa kelekatan dengan orangtua merupakan salah satu faktor yang dapat mempengaruhi keintiman pada saat berpacaran atau menjalin hubungan, diharapkan melalui penelitian ini individu dapat mengoreksi dan melihat lagi kelekatan atau hubungan yang dimiliki dengan orangtuanya berdampak pada hubungan dengan pasangannya sehingga dapat mencegah terjadinya permasalahan dalam hubungan berpacaran.

2. Bagi peneliti selanjutnya yang akan meneruskan penelitian ini dapat memperhatikan juga mengenai usia berpacaran subjek, perbedaan jenis kelamin, serta faktor lainnya (misalnya: kecemasan terhadap identitas diri).

\section{DAFTAR PUSTAKA}

Agusdwitanti, H., Tambunan, S. M., \& Retnaningsih. (2015). Kelekatan dan intimasi pada dewasa awal. Jurnal Psikologi. 1(8), 13-14.

Baradja, A. (2005). Psikologi perkembangan: tahapan-tahapan dan aspekaspeknya. Jakarta: Studia Press.

Bowlby, J. (1998). A secure base: parentchild attachment and healthy human development. New York: Basic Books.

Cassidy, J., \& Shaver, P. R. (1999). Handbook of attachment: theory, research, and clinical application. New York: The Guilford Press.

Colin, V. L. (1996). Human attachment. United States of America: Mc GrawHill.

Cox, F. D. (1978). Human intimacy, marriage, the family and it's meaning. Minnesata: West Publishing, Co.

Dacey, J., \& Kenny, M. (1997). Adolesence development ( $2 \mathrm{nd} \mathrm{Ed}$ ). United States of America: Times Mirror Higher Education Group Inc.

Eliasa, E. I. (2000). Pentingnya kelekatan orangtua dalam internal working model untuk pembentukan karakter anak. Skripsi diterbitkan. Yogyakarta: Universitas Negri Yogyakarta.

Ervika, E. (2005). Kelekatan (attachment) pada anak. Jurnal Psikologi.1(3), 2-4.

Guarnieri, S., Ponti, L., \& Franca, T. (2010). The inventory of parent and peer attachment (IPPA): a studi on the validity of styles of adolescent attachment to parents and peers in an Italian sample. TPM, 17(3), 103130.

Greenberg, M.T., \& Armsden, G. (1987). Inventory of Parent and Peer Attachment.

Hazan, C., \& Shaver. P. (1987). Romantic love conceptualized as an attachment process. www. Psych. Nwu. edu/coriat/Love.htm.

Lefrancois, G. R. (1993). The life span (4th Ed). California: Wadsworth, Inc. 
Lemme, B. (1995). Development in adulthood (2nd ed). New york: McGraw-Hill.

Linder, D. (2007). Intimacy: the essence of true love. Inkstone Press Pty.

Marcia, \& James, E. (1993). Ego identity: a handbook for psychosocial research. Springer-Verlag: New York.

Olson, D. H., \& Defrain, J. (2006). Marriage family: intimacy, diversity, and strengths (5th Ed). New York: McGraw-Hill.

Olson, D. H., \& Schaefer, M. T. (1981). Assessing intimacy: the PAIR inventori. journal of marital and family therapy.

Papalia, D. E., Olds, S.W., \& Feldman, R. D. (2004). Human development (perkembangan manusia edisi 3). Jakarta: Salemba Humanika.

Pramana, W. (1996). The utility of theories of parenting, attachment, stress and stigma in predicting adjusment to illnes. Disertasi. Departement of psychology the University of Queesnland

Santrock, J. W. (2002). Life-span development (perkembangan masa hidup), Edisi 5, Jilid 1. Jakarta: Erlangga.

(2003). Adolescence, sixth edition. Jakarta: Erlangga. (2007). Adolecence, eleventh edition. Jakarta: Erlangga.

Shaver, P. R., \& Clark, C. L. (1994). The psychodynamics ofadult romantic attachment. In J. M. Masling \& R. F. Bornstein (Eds.), Empirical perspective on object relations theories. Washington, DC: American Psychological Association.
Sidjabat, S. L. (2015), Studi mengenai hubungan antara pola attachment ayah-anak perempuan dengan kapasitas intimacy wanita terhadap lawan jenis pada masa sewasa awal. Jurnal Psikologi. 2(1), 1-10

Sternberg, R. J. (1997). Construct validation of a triangular love scale. Journal of Social Psychology, 2(27), 313-335.

Sugiyono, (2011). Statistika untuk penelitian. Bandung: Alfabeta.

Suryabrata, S. (2004). Metodologi penelitian. Jakarta: PT. Raja Grafindo Persada.

Vebrianingsih, C. W. (2014). Gaya kelekatan sebagai prediktor tingkat keintiman dalam hubungan berpacaran pada individu di masa dewasa awal. Jurnal psikologi. 3(2), 1-17.

Yessy, (2003). Hubungan pola attachment dengan kemampuan menjalin relasi pertemanan pada remaja. Jurnal Psikologi. 2(12), 1-12.

Yeniza, R. (2007). Hubungan antara intimacy dengan kecemburuan pada remaja yang berpacaran. Skripsi. Universitas Gunadarma. 